\title{
A comparative study on the basis of adsorption capacity between CNTs and activated carbon as adsorbents for removal of noxious synthetic dyes: a review
}

\author{
Karim Zare ${ }^{1,2}$ • Vinod Kumar Gupta ${ }^{3,4,5,6}$ - Omid Moradi ${ }^{7}$. \\ Abdel Salam Hamdy Makhlouf ${ }^{8} \cdot$ Mika Sillanpääa $^{9}$ Mallikarjuna N. Nadagouda ${ }^{10}$ \\ Hamidreza Sadegh $^{1}$ - Ramin Shahryari-ghoshekandi ${ }^{1}$ - Angshuman Pal ${ }^{11}$. \\ Zhou-jun Wang ${ }^{12} \cdot$ Inderjeet Tyagi $^{3} \cdot$ Maryam Kazemi $^{13}$
}

Received: 5 February 2015/ Accepted: 6 April 2015/Published online: 22 April 2015

(c) The Author(s) 2015. This article is published with open access at Springerlink.com

\begin{abstract}
Rapid removal of noxious synthetic dyes from wastewater is of great concern in the scientific research field, this is due to the expansion of harmful effects of synthetic dyes traces in water streams on the environment and human health with the exponential rise in concentration of synthetic dye globally and demand in various industries that coincided with the implantation of more stringent water quality standards. Various technologies have been applied for the removal of synthetic dye from wastewater, including adsorption technology, which has a great potential in treating varieties of synthetic dyes. This article comprehensively reviews the latest progress in the development of carbon nanotubes (CNTs) and their applications for the removal of synthetic dyes from
\end{abstract}

Karim Zare

k-zare@sbu.ac.ir; k.zare@bpj.ir

$\triangle$ Vinod Kumar Gupta

vinodfcy@iitr.ac.in; vinodfcy@gmail.com

Omid Moradi

moradi.omid@gmail.com; o.moradi@shahryariau.ac.ir

Abdel Salam Hamdy Makhlouf

asalam85@yahoo.com; makhloufah@utpa.edu

Mika Sillanpää

Mika.Sillanpaa@lut.fi

Mallikarjuna N. Nadagouda

nadagouda.mallikarjuna@epa.gov

Hamidreza Sadegh

h.sadegh@chemist.com

Ramin Shahryari-ghoshekandi

r.shahreyari@chemist.com

Angshuman Pal

apal@clarkson.edu

Zhou-jun Wang

wangzj@mail.buct.edu.cn wastewater, including functionalized of CNTs and their researched counterparts. The emerging trends in the development of alternative adsorbents with different substrates, morphologies, and functional groups are also elucidated.

Keywords Carbon nanotubes (CNTs) - Activated carbon (AC) - Synthetic dyes · Adsorption · Functionalization · Wastewater treatment

$\begin{array}{ll}\text { Abbreviations } & \\ \text { AB161 } & \text { Acid blue 161 } \\ \text { AC } & \text { Activated carbon } \\ \text { AR18 } & \text { Acid red 18 }\end{array}$

Inderjeet Tyagi

indertyagi011@gmail.com

Maryam Kazemi

maryamkazemi691026@gmail.com

1 Department of Chemistry, Science and Research Branch, Islamic Azad University, Tehran, Iran

2 Department of Chemistry, Shahid Beheshti University, Evin, Tehran, Iran

3 Department of Chemistry, Indian Institute of Technology Roorkee, Roorkee 247667, India

4 Department of Chemistry, King Fahd University of Petroleum and Minerals Dhahran, Dhahran, Saudi Arabia

5 Center for Environment and Water, The Research Institute, King Fahd University of Petroleum and Minerals Dhahran, Dhahran 31261, Saudi Arabia

6 Department of Applied Chemistry, University of Johannesburg, Johannesburg, South Africa

7 Department of Chemistry, Shahr-e-Qods Branch, Islamic Azad University, Tehran, Iran 


$\begin{array}{ll}\text { AR183 } & \text { Acid red } 183 \\ \text { ARS } & \text { Alizarin red S } \\ \text { BR } & \text { Bromopyrogallol red } \\ \text { BR46 } & \text { Basic red 46 } \\ \text { BTB } & \text { Bromothymol blue } \\ \text { Cd } & \text { Cadmium hydroxide nanowire-loaded } \\ (\mathrm{OH})_{2} \text {-NW-AC } & \text { activated carbon } \\ \text { CNF } & \text { Carbon nanofibers } \\ \text { CNTs } & \text { Carbon nanotubes } \\ \text { CR } & \text { Congo red } \\ \text { CSBs } & \text { CNT-impregnated chitosan hydrogel } \\ & \text { beads } \\ \text { DMBAR } & \text { 5-(4-dimethyl benzylidene amino) } \\ & \text { Rhodanine } \\ \text { HCNTs } & \text { Hybrid CNTs } \\ \text { MB } & \text { Methyl blue } \\ \text { MG } & \text { Methyl green } \\ \text { MO } & \text { Methyl orange } \\ \text { MR } & \text { Methyl red } \\ \text { MWCNTs } & \text { Multi-walled carbon nanotubes } \\ \text { OII } & \text { Orange II } \\ \text { PAC } & \text { Powdered activated carbon } \\ \text { PAHs } & \text { Poly-aromatic hydrocarbons } \\ \text { RB29 } & \text { Reactive blue 29 } \\ \text { RB4 } & \text { Reactive blue 4 } \\ \text { RR120 } & \text { Reactive red 120 } \\ \text { RRM } & \text { Reactive red M-2BE } \\ \text { SDS } & \text { Sodium dodecyl sulfate } \\ \text { SO } & \text { Safranine O } \\ \text { SWCNTs } & \text { Single-walled carbon nanotubes } \\ \text { TB } & \text { Toluidine blue } \\ & \end{array}$

\section{Introduction}

The application of carbon nanomaterials such as carbon nanotubes (CNTs) in the field of adsorption is one of the emerging trends for the removal of dyes from wastewater,

8 Department of Manufacturing Engineering, College of Engineering and Computer Science, University of Texas PanAmerican, Edinburg, USA

9 Laboratory of Green Chemistry, Lappeenranta University of Technology, Sammonkatu 12, 50130 Mikkeli, Finland

10 National Risk Management Research Laboratory, US Environmental Protection Agency, WSWRD, TTEB, Cincinnati, OH, USA

11 Chemistry and Biomolecular Science, Clarkson University, Potsdam, NY 13699, USA

12 State Key Laboratory of Chemical Resource Engineering, Beijing University of Chemical Technology, 15 Beisanhuan East Road, Chaoyang District,

P. O. Box 266, Beijing 100029, People's Republic of China

13 Department of Chemistry, Payame Noor University, Zanjan, Iran even at very low concentrations [1]. CNTs can be visualized as graphitic carbon sheets rolled into hollow cylinders with nanometer-scale diameters and micrometer-scale lengths $[2,3]$. Owing to their unique properties, the production and chemical variations of CNTs has been growing rapidly [4]. These chemical variations are created by the unique bonding configurations of carbon that make it a ubiquitous part of our environment. The one-dimensional nature of the basic CNT structure enables ultra-high surface area, the ability to act as a semiconductor or a metal, the existence of multiple direct band gaps, the relative ease of attachment for numerous chemical functional groups, and the ability to decorate CNTs with nanoparticles [4-7].

In this review, we highlight the past and present attempts for using CNTs as adsorbents for the removal of synthetic dyes. Furthermore, the effect of surface modification of CNTs by synthetic dyes is in the core of this review.

\section{Synthetic dyes}

The major structure element responsible for light absorption in dye molecules is the chromosphere group, i.e., a delocalized electron system with conjugated double bonds. Usually chromospheres contain heteroatoms such as $\mathrm{N}, \mathrm{O}$, and $\mathrm{S}$, with non-bonding electrons. Common classes of dyes, based on the chromosphere present, are shown in Table 1 [8-11]. Dyes were also usually classified based on their particle charge upon dissolution in aqueous application medium [12, 13], to cationic (all basic dyes), anionic (direct, acid, and reactive dyes), and non-ionic (dispersed dyes) as shown in Table $2[14,15]$.

\section{Carbon nanotubes (CNTs)}

The discovery of carbon nanotubes in 1991 by Iijima [16] brought revolutionary changes into the field of nano-adsorbents during the last decade that showed a boom as evidenced from the huge number of literature. Carbon nanotubes are basically rolled up graphene sheets (hexagonal structures) into cylindrical form and capped with half shape of fullerene structure [5]. There are two types of carbon nanotubes (Fig. 1): (a) single-walled carbon nanotubes (SWCNTs), that can be considered as a single graphene sheet rolled into a cylinder and (b) multi-walled carbon nanotubes (MWCNTs), which can be considered as stacking of concentric layers of several graphene sheets in the form of cylinders with an interspacing of $0.34 \mathrm{~nm}$. Based on the atomic arrangement there are three types of structures: (1) zigzag, (2) armchair and (3) chiral structures (Fig. 2) [5, 17]. The properties of carbon nanotubes are 
Table 1 Synthetic dye structures according to their chromophores adapted from [8-11]

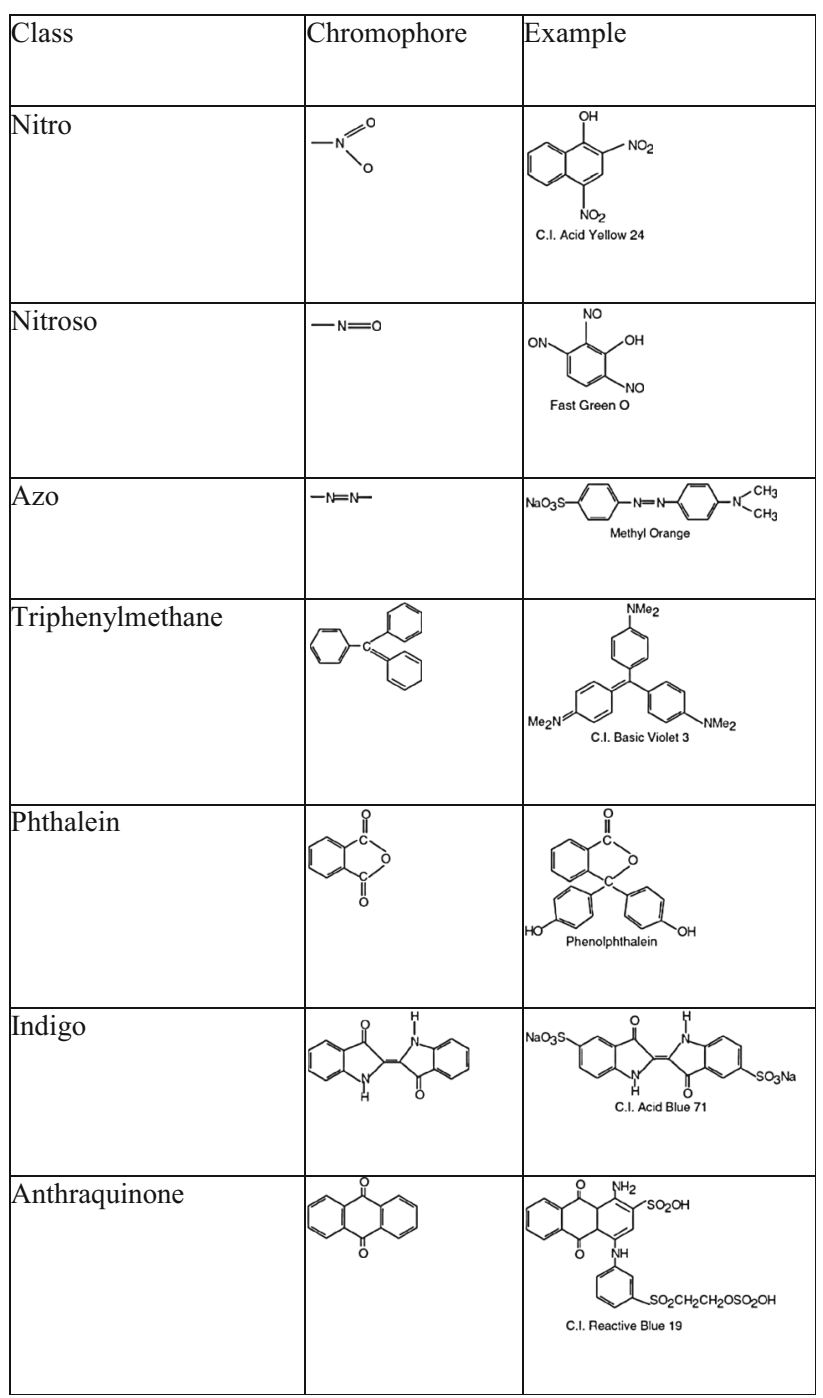

highly dependent on morphology, size and diameter [3]. Carbon nanotubes can be metallic or semiconducting depending on the atomic arrangement of carbon nanotubes. Initially, MWCNTs were prepared by Iijima using arc evaporation method in 1991 [16-18]. Later on, the same researcher reported the discovery of SWCNT in 1993 prepared by arc evaporation of metal impregnated (Fe-graphite) electrodes in the presence of methane-argon [18, 19].

In addition to the pioneer study of Iijima for the preparation of MWCNTs and SWCNT using arc evaporation method [16-19], other methods have been reported including laser ablation [19], chemical vapor deposition [20], electrolysis [20], flame synthesis [19], etc. It is worth mentioning that arc evaporation method, laser ablation and chemical vapor deposition are the most common techniques which are used broadly for synthesis of CNTs [20, 21].
The adsorptive surface of the CNTs by nature is highly hydrophobic [21]. To overcome this problem in raw CNTs, different methods of surface modification have been pursued using non-covalent [22] and covalent functionalization [23] strategies.

CNTs surface modifications have been conventionally classified mainly into three categories depending on the method for achieving modification [24, 25]: (1) mechanical, (2) physicochemical, and (3) irradiation. Physicochemical methods had been most widely adopted, namely, covalent surface modification and non-covalent surface modification, depending on whether or not covalent bonding between the CNTs and the functional groups and/ or modifier molecules is involved in the surface modification process [24-27].

Non-covalent functionalization strategies do not have any effect on the physical properties of the CNTs because they keep the structure of intrinsic $s p^{2}$ hybridized orbital unchanged. This can be done by taking advantage of the $\pi-$ $\pi$ interaction between conjugated molecules and the graphitic sidewall of CNTs [24-26]. Other methods such as non-covalent hydrophobic interactions (amphiphilic molecules) with aromatic surface of CNTs in aqueous media have also been explored, which can reduce the hydrophobic interface between the CNTs and their polar environment [27-33].

Covalent functionalization depends on the chemical reaction between the carbon atoms of CNTs and conjugation of hydrophilic organic molecules on the surface of CNTs. The 'ends and defects' and 'side walls' functionalizations are the two subcategories of covalent functionalization, whereas the former one is more specific and reactive than the later [28-34].

The chemical treatment of pristine CNTs with most widely used strong oxidative agents (concentrated $\mathrm{H}_{2} \mathrm{SO}_{4}$ and $\mathrm{HNO}_{3}$ with molar ratio 3:1) generate the oxygenated groups such as carboxylic, ketone, alcohol, and ester at 'ends and defects' sites of CNTs. This treatment not only generates the various functional groups, but also cut and shortens the CNTs into the smaller pieces. Side wall functionalization introduces higher concentration of covalently attached functional groups on the CNTs surface with the trade-off of significant perturbation in the electronic structure [35-38]. A more detailed account about the recent progress in the chemical modifications of CNTs was reviewed by Karousis et al. [39]. In this review, we summarized the different functionalization schemes of CNTs in Fig. 3. This shows that different functionalities have added on CNT surfaces through different routes. Such treatments increase the affinity of CNT towards wastewater pollutants, which are subsequently trapped into the nanotube's surface [17]. 
Table 2 Classification of dyes based on their chemical nature adapted from [14, 15]

\begin{tabular}{|c|c|c|c|}
\hline Class & Substrate & Method of application & Chemical types \\
\hline Acid dyes & $\begin{array}{l}\text { Wool, nylon, silk, inks, leather and } \\
\text { paper }\end{array}$ & Generally from neutral to acidic bath & $\begin{array}{l}\text { Anthraquinone, xanthene, azo, nitro, } \\
\text { and triphenylmethane }\end{array}$ \\
\hline Basic dyes & $\begin{array}{l}\text { Inks, paper, polyacrylonitrile, treated } \\
\text { nylon, and polyester }\end{array}$ & Applied from acidic dye baths & $\begin{array}{l}\text { Hemicyanine, azo, cyanine, } \\
\text { diazahemicyanine, azine, } \\
\text { diphenylmethane, xanthene, } \\
\text { triarylmethane, acridine, } \\
\text { anthraquinone and oxazine }\end{array}$ \\
\hline Direct dyes & $\begin{array}{l}\text { Nylon, rayon, paper, leather and } \\
\text { cotton }\end{array}$ & $\begin{array}{l}\text { Applied from neutral or a little } \\
\text { alkaline bath containing additional } \\
\text { electrolyte }\end{array}$ & $\begin{array}{l}\text { Phthalocyanine, azo, oxazine, and } \\
\text { stilbene }\end{array}$ \\
\hline Disperse dyes & $\begin{array}{l}\text { Polyamide, acrylic polyester, acetate, } \\
\text { and plastics }\end{array}$ & $\begin{array}{l}\text { Fine aqueous dispersions often applied } \\
\text { by high-temperature/pressure or } \\
\text { lower temperature carrier methods; } \\
\text { dye may be padded on cloth and } \\
\text { thermo fixed }\end{array}$ & $\begin{array}{l}\text { Benzodifuranone, azo, anthraquinone, } \\
\text { nitro, and styryl }\end{array}$ \\
\hline Reactive dyes & Wool, cotton, silk and nylon & $\begin{array}{l}\text { Reactive site on dye reacts with } \\
\text { functional group on fiber to bind dye } \\
\text { covalently under influence of heat } \\
\text { and } \mathrm{pH}\end{array}$ & $\begin{array}{l}\text { Anthraquinone, formazan, } \\
\text { phthalocyanine, azo, oxazine and } \\
\text { basic }\end{array}$ \\
\hline Sulphur dyes & Rayon and cotton & $\begin{array}{l}\text { Aromatic substrate vatted with sodium } \\
\text { sulphide and reoxidized to insoluble } \\
\text { sulphur-containing products on fiber }\end{array}$ & Indeterminate structures \\
\hline Vat dyes & Wool and cotton & $\begin{array}{l}\text { Water-insoluble dyes solubilized by } \\
\text { dropping in sodium hydrogen } \\
\text { sulphite, then exhausted on } \\
\text { reoxidized and fiber }\end{array}$ & Indigoids and anthraquinone \\
\hline
\end{tabular}

(a)

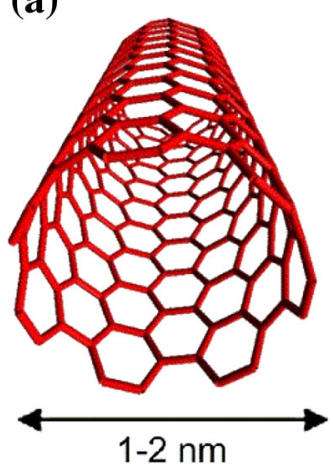

(b)

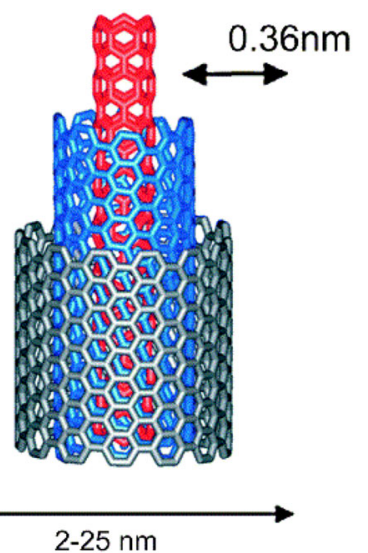

Fig. 1 Schematics of a SWCNTs (a) and MWCNTs (b)

Treatment with different acidic and oxidizing agents on CNTs leads to different surface area and adsorption capacity. Some of them are listed in Table 3 with corresponding surface area and adsorption capacities [40]. In addition, functionalities can increase the solubility of CNTs and bring CNTs to repulse each other, which help free movement of individual CNT in homogeneous solution without aggregation. Aggregation can decrease the affinity of interactions between synthetic dyes and nanotube surfaces [17].

\section{Adsorption of synthetic dyes on CNTs and a comparison with activated carbon (AC)}

Adsorption is commonly employed as a polishing step to remove synthetic dyes contaminants in wastewater treatment. Efficiency of conventional adsorbents is usually limited by the surface area or active sites, the lack of selectivity, and the adsorption kinetics [41]. CNT adsorbents offer significant improvement with their extremely high specific surface area and associated sorption sites, short intraparticle diffusion distance, and tunable pore size and surface chemistry [42]. In addition, CNTs can be considered as one of the most promising absorbents for this purpose because of their large adsorption capacity for synthetic dyes [5]. Indeed, MWCNTs have been shown to outperform cadmium hydroxide nanowire-loaded AC $\left(\mathrm{Cd}(\mathrm{OH})_{2}-\mathrm{NW}-\mathrm{AC}\right)$ with respect to their efficient removal of safranine $\mathrm{O}(\mathrm{SO})$ from wastewater [43]. However, only a few studies on the application of CNTs for dye removal from aqueous solution have been reported [44-49] and the CNTs were typically directly used without further treatment [45-47, 49] (Table 4).

Functionalization of CNTs has been undertaken because the introduction of various functional groups can provide new adsorption sites for synthetic dyes. Among such modifications, oxidation is an easy method of introducing 
Fig. 2 Molecular models of exhibited by SWNTs based on the chirality

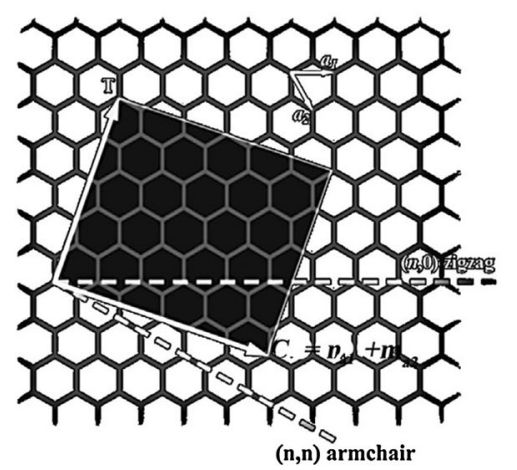

$(10,10)$ nanotube (armchair)

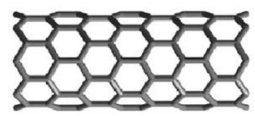

$(0,10)$ nanotube

(zig-zag)

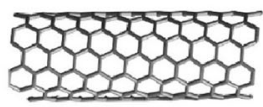

$(7,10)$ nanotube

(chiral) hydroxyl and carbonyl groups to the sidewalls of CNTs. Oxidized MWCNTs have been shown to be effective in the removal of methyl red (MR) [50] and methylene blue (MB) from aqueous solutions [51].

Mahmoodian et al. [52] studied the adsorption of methyl orange (MO) onto pHEMA-CS-f-MWCNT and reported an adsorption capacity of $306 \mathrm{mg} \mathrm{g}^{-1}$ for removal of MO onto CNTs. Shahryari et al. [53] performed the same batch of experiments on MWCNTs having a higher surface area of $280 \mathrm{~m}^{2} /$ $\mathrm{g}$ as compared to that of CNTs used by Mahmoodian et al. and reported a higher methyl blue (MB) adsorption of $132.6 \mathrm{mg} \mathrm{g}^{-1}$ at $310 \mathrm{~K}$. We suggest that the adsorption capacity also depends on the experimental conditions and nature and type of the adsorbent. In ref. [53] the authors used MWCNTs as adsorbent while ref. [52] reported the use of CNTs.

Rodríguez et al. [54] compared the adsorption capacity of cationic MB and anionic orange II (OII) from aqueous solution by using MWNTs and carbon nanofibers (CNF) as adsorbents. The adsorption of MB onto CNF was slightly higher than adsorption onto MWCNTs, while for OII the adsorption capacity of CNF was $(66.12 \pm 2.11) \mathrm{mg} \mathrm{g}^{-1}$ and MWCNTs was $77.83 \pm 1.6 \mathrm{mg} \mathrm{g}^{-1}$.

In another study, the reverse adsorption capacity was observed for the removal of Reactive Red M-2BE (RRM) onto MWCNTs and powdered activated carbon (PAC) while PAC had a higher surface area of $728.7 \mathrm{~m}^{2} / \mathrm{g}$ than that of MWCNTs $\left(180.9 \mathrm{~m}^{2} / \mathrm{g}\right)$ [55]. The maximum amounts of RRM uptake were 335.7 and $260.7 \mathrm{mg} \mathrm{g}^{-1}$ for MWCNT and PAC, respectively. Accordingly, we can justify the higher adsorption capacity on the basis of the higher average pore diameter of MWCNTs which was $7.62 \mathrm{~nm}$ as compared to $3.52 \mathrm{~nm}$ for PAC. Due to the larger pore size, the dyes molecules can easily be diffused form surface though the pores of MWCNTs.

The development of CNT-impregnated chitosan hydrogel beads (CSBs) for the removal of Congo red (CR) has been investigated [56, 57]. In Langmuir adsorption modeling, CSBs demonstrated a higher maximum adsorption capacity than normal chitosan CBs (450.4 vs. $200.0 \mathrm{mg} \mathrm{g}^{-1}$ ) [56]. A new generation of CSBs prepared by using sodium dodecyl sulfate (SDS) and MWCNTs to improve their mechanical properties has demonstrated a high maximum adsorption capacity for $\mathrm{CR}$ (375.94 $\mathrm{mg} \mathrm{g}^{-1}$ ) [57]. Compared to MWCNTs and hybrid CNTs (HCNTs), SWCNTs can demonstrate better adsorption properties for organic contaminants because of their higher specific surface area [41]. Indeed, SWCNTs are more efficient for the removal of benzene and toluene, and has shown maximum adsorption capacities of 9.98 and $9.96 \mathrm{mg} \mathrm{g}^{-1}$, respectively [58]. A maximum adsorption capacity of $496 \mathrm{mg} \mathrm{g}^{-1}$ was achieved when reactive blue 29 (RB29) was removed from aqueous solution using SWCNTs [59, 60].

CNTs have shown higher efficiency than AC on adsorption of various synthetic dyes [73]. The high adsorption capacity mainly stems from the large specific surface area and the diverse contaminant-CNT interactions. The available surface area for adsorption on individual CNTs is their external surfaces [74]. In the aqueous phase, CNTs form loose bundles/aggregates due to the hydrophobicity of their graphitic surface, reducing the effective surface area [73-75]. On the other hand, CNT aggregates contain interstitial spaces and grooves, which are high adsorption energy sites for organic molecules [75]. Although activated carbon possesses comparable measured specific surface area as CNT bundles, it contains a significant number of microspores inaccessible to bulky organic molecules such as many antibiotics and pharmaceuticals [76]. Thus CNTs have much higher adsorption capacity for some bulky organic molecules because of their larger pores in bundles and more accessible sorption sites.

A major drawback of AC is its low adsorption affinity for low molecular weight polar organic compounds. CNTs strongly adsorb many of these polar organic compounds due to the diverse contaminant-CNT interactions including hydrophobic effect, $\pi-\pi$ interactions, hydrogen bonding, covalent bonding, and electrostatic interactions [74]. The $\pi$ electron-rich CNT surface allows $\pi-\pi$ interactions with organic molecules with $\mathrm{C}=\mathrm{C}$ bonds or benzene rings, such as poly-aromatic hydrocarbons (PAHs) and polar aromatic compounds [77, 78]. Organic compounds which have $\mathrm{COOH},-\mathrm{OH},-\mathrm{NH}_{2}$ functional groups could also form hydrogen bond with the graphitic CNT surface which 
Fig. 3 Surface

functionalization of CNTs

through different routes: normal methods (a), other related methods (b) (a)

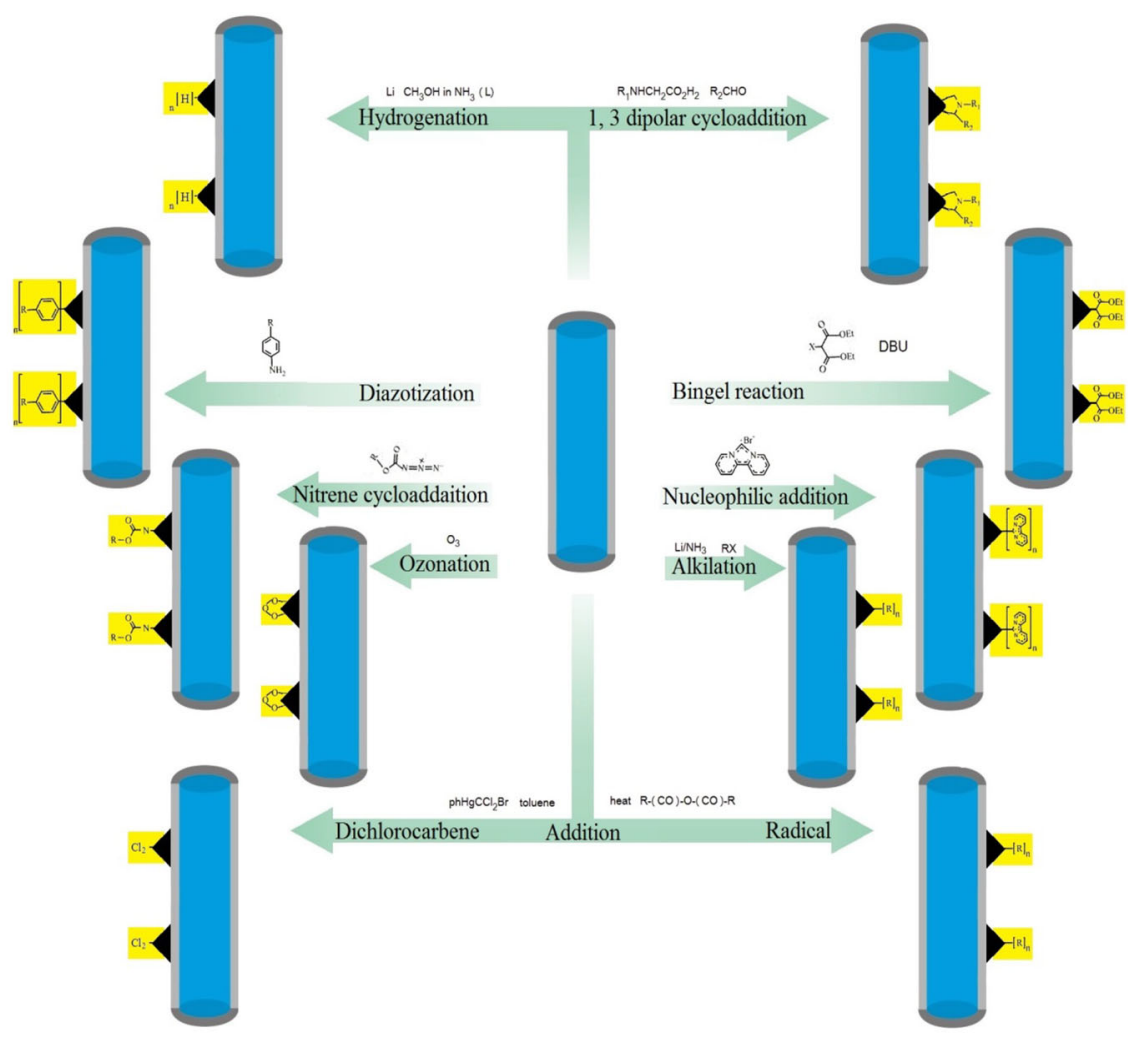

(b)
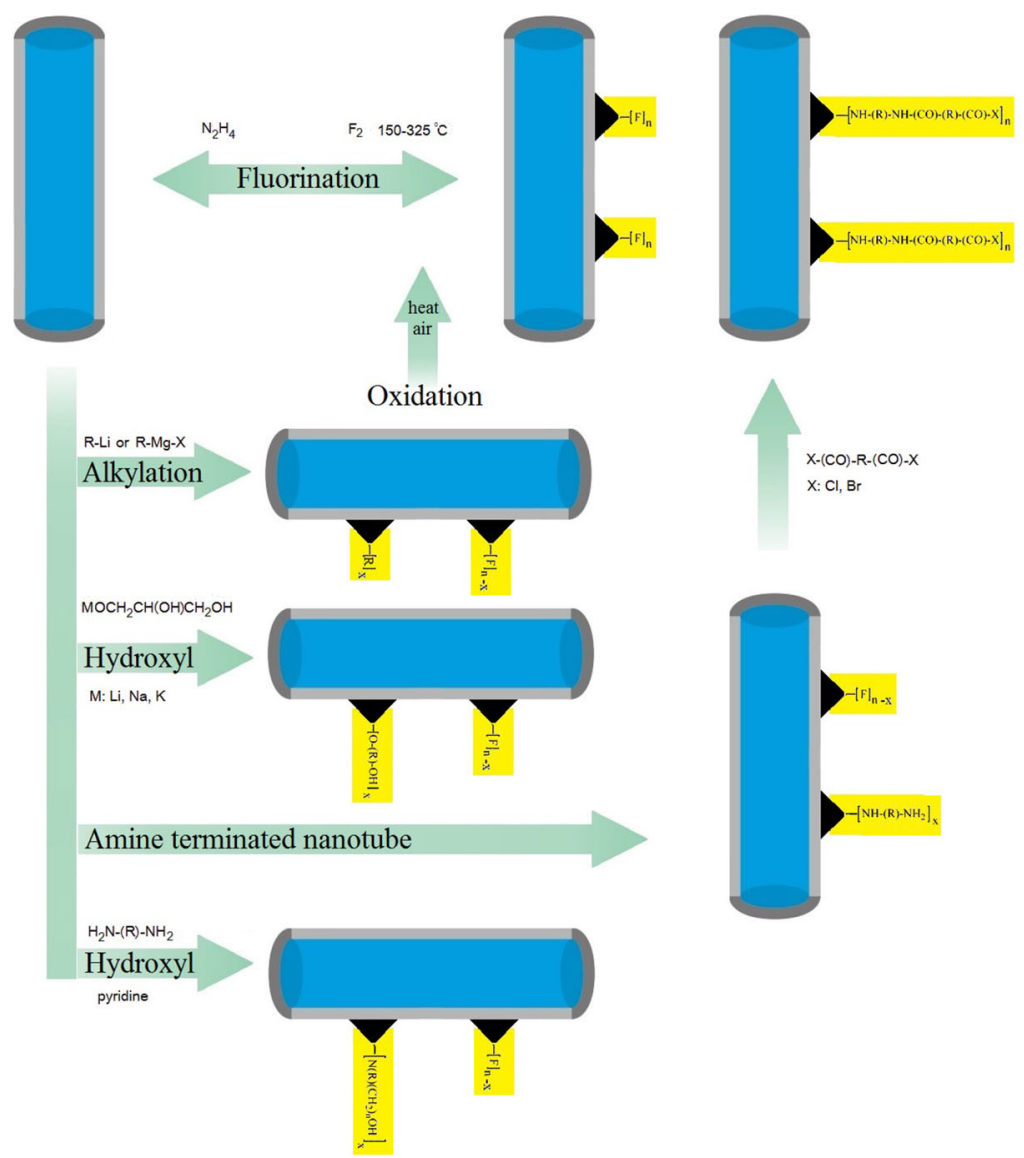
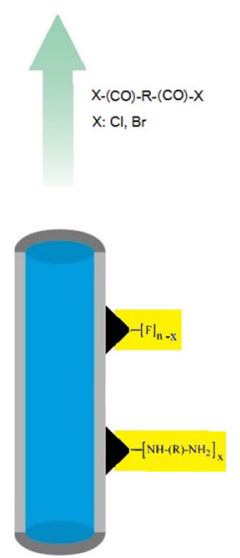
donates electrons [79, 80]. Electrostatic attraction facilitates the adsorption of positively charged organic chemicals such as some antibiotics at suitable $\mathrm{pH}$ [76].

Table 3 Adsorption capacities and surface area of CNTs [40]

\begin{tabular}{lcc}
\hline CNTs $\left(\mathrm{m}^{2} / \mathrm{g}\right)$ & Adsorption capacity $(\mathrm{mg} / \mathrm{g})$ & Surface area \\
\hline Pristine CNTs & 1.10 & 82.20 \\
$\mathrm{H}_{2} \mathrm{O}_{2}$ oxidized & 2.60 & 130.0 \\
$\mathrm{HNO}_{3}$ oxidized & 5.10 & 84.30 \\
$\mathrm{KMnO}_{4}$ oxidized & 11.00 & 128.0 \\
\hline
\end{tabular}

\section{Conclusion}

This article reviews the different adsorption technique using CNTs used for the removal of synthetic dyes from wastewaters. Many reports confirmed that CNTs have higher efficiency than $\mathrm{AC}$ on the adsorption of various synthetic dyes. A wide range of CNT-based adsorbents obtained from surface modification of CNTs has been investigated. Several researchers demonstrated that the surface modification of CNTs has a high impact on improving their performance and ability to adsorb synthetic dyes from aqueous solutions. It has also been demonstrated that

Table 4 Removal of synthetic dyes using CNTs

\begin{tabular}{|c|c|c|c|c|}
\hline CNTs & Modification method & $\begin{array}{l}\text { Dye } \\
\text { adsorbed }\end{array}$ & $\begin{array}{l}\text { Adsorption } \\
\text { effect }\left(\mathrm{mg} \mathrm{g}^{-1}\right)\end{array}$ & References \\
\hline SWCNTs & Pristine & BR46 & 38.35 & [41] \\
\hline SWCNTs & Oxidized & BR46 & 49.45 & [41] \\
\hline MWCNTs & Refluxed pristine MWCNTs in concentrated $\mathrm{HNO}_{3} / \mathrm{H}_{2} \mathrm{SO}_{4}$ mixture for $4 \mathrm{~h}$ & $\begin{array}{l}\text { TB, MB, } \\
\text { MG, BR }\end{array}$ & Not provided & [44] \\
\hline MWCNTs & Untreated & ARS & 161.290 & [45] \\
\hline MWCNTs & Untreated & morin & 26.247 & [45] \\
\hline MWCNTs & Untreated & ECR & 73.18 & [46] \\
\hline MWCNTs & Untreated & Arsenazo(III) & Not provided & [47] \\
\hline MWCNTs & Oxidized using concentrated nitric acid & MO & Not provided & [48] \\
\hline MWCNTs & Untreated & RRM & 335.7 & [49] \\
\hline MWCNTs & Oxidized & MR & 108.7 & {$[50]$} \\
\hline MWCNTs & Oxidized & ВТВ & 55.3 & {$[51]$} \\
\hline MWCNTs & Oxidized and microwave method & MO & 306 & {$[52]$} \\
\hline MWCNTs & Untreated & MB & 132.6 & [53] \\
\hline MWCNTs & Untreated & MB & $77.83 \pm 1.6$ & {$[54]$} \\
\hline MWCNTs & Untreated & RRM & 335.7 & {$[55]$} \\
\hline MWCNTs & CNT-impregnated chitosan hydrogel beads (CSBs) & $\mathrm{CR}$ & 450.4 & {$[56]$} \\
\hline MWCNTs & CSBs prepared by using sodium dodecyl sulfate (SDS) & $\mathrm{CR}$ & 375.94 & [57] \\
\hline SWCNTs & Untreated & RB29 & 496 & [59] \\
\hline MWCNTs & Untreated & $\mathrm{CR}$ & Not provided & {$[61]$} \\
\hline MWCNTs & Untreated & MO & Not provided & {$[62]$} \\
\hline MWCNTs & Alkali-activated & MB & 399 & {$[63]$} \\
\hline MWCNTs & Alkali-activated & MO & 149 & {$[63]$} \\
\hline MWCNTs & Untreated & AR18 & 166.67 & {$[64]$} \\
\hline MWCNTs & Untreated & MB & 59.7 & [65] \\
\hline MWCNTs & Untreated & AR183 & 5.2 & {$[65]$} \\
\hline MWCNTs & Untreated & $\mathrm{AB} 161$ & $91.68 \%$ & [66] \\
\hline MWCNTs & Untreated & RB4 & 69 & [67] \\
\hline MWCNTs & Untreated & AR183 & 45 & [67] \\
\hline MWCNTs & $\begin{array}{l}\text { Fabricated magnetic MWCNTs by Fenton's reagent method } \\
\text { (M-MWCNTs) }\end{array}$ & MO & 28 & [68] \\
\hline MWCNTs & Oxidized & DMBAR & 15.52 & [69] \\
\hline MWCNTs & $\begin{array}{l}\text { Produced by Ni nanoparticle catalyzed pyrolysis of methane in a hydrogen } \\
\text { and nitrogen flow at } 6500^{\circ} \mathrm{C}\end{array}$ & MB & 188.68 & [70] \\
\hline MWCNTs & Untreated & Triclosan & 153.1 & [71] \\
\hline SWCNTs & Untreated & RR120 & 426.49 & [72] \\
\hline
\end{tabular}


surface modification of CNTs, in general, improves the adsorption capacity of adsorbents probably due to the increased number of active binding sites resulting from surface modification and formation of new functional groups that favors the adsorption of synthetic dyes. Although surface modification of CNTs can enhance the adsorption of synthetic dyes, the cost of chemicals used and methods of modification also have to be taken into consideration. As far as the modification of an adsorbent surface might change the overall properties of the adsorbent, characterization studies involving surface area pore size, porosity are recommended for any future work on surface modification of CNTs.

Acknowledgments The authors would like to thank Islamic Azad University.

Open Access This article is distributed under the terms of the Creative Commons Attribution 4.0 International License (http:// creativecommons.org/licenses/by/4.0/), which permits unrestricted use, distribution, and reproduction in any medium, provided you give appropriate credit to the original author(s) and the source, provide a link to the Creative Commons license, and indicate if changes were made.

\section{References}

1. Gong, J.L., Wang, B., Zeng, G.M., Yang, C.P., Niu, C.G., Niu, Q.Y., Liang, Y.: Removal of cationic dyes from aqueous solution using magnetic multi-wall carbon nanotube nanocomposite as adsorbent. J. Hazard. Mater. 164(2), 1517-1522 (2009)

2. Zare, K., Najafi, F., Sadegh, H., Shahryari Ghoshekandi, R.: Studies of ab initio and Monte Carlo simulation on interaction of fluorouracil anticancer drug with carbon nanotube. J. Nanostruct. Chem. 3(1), 1-8 (2013)

3. Moradi, O., Sadegh, H., Shahryari-Ghoshekandi, R., Norouzi, M.: Application of carbon nanotubes in nanomedicine: new medical approach for tomorrow. In: Soni, S., Salhotra, A., Suar, M. (eds.) Handbook of Research on Diverse Applications of Nanotechnology in Biomedicine, Chemistry, and Engineering, pp. 90-128. (2015). doi:10.4018/978-1-4666-6363-3.ch006. Accessed 16 Jan 2015

4. Wang, X., Lu, J., Xing, B.S.: Sorption of organic contaminants by carbon nanotubes: influence of adsorbed organic matter. Environ. Sci. Technol. 42(9), 3207-3212 (2008)

5. Gupta, V.K., Kumar, R.: Adsorptive removal of dyes from aqueous solutions onto carbon nanotubes: a review. Adv. Colloid Interface Sci. 193, 24-34 (2013)

6. Moradi, O., Fakhri, A., Adami, S., Adami, S.: Isotherm, thermodynamic, kinetics, and adsorption mechanism studies of Ethidium bromide by single-walled carbon nanotube and carboxylate group functionalized single-walled carbon nanotube. J. Colloid Interface Sci. 395, 224-229 (2013)

7. Khani, H., Moradi, O.: Influence of surface oxidation on the morphological and crystallographic structure of multi-walled carbon nanotubes via different oxidants. J. Nanostruct. Chem. 3(1), 73 (2013)

8. Ali, H.: Biodegradation of synthetic dyes-a review. Water Air Soil Pollut. 213(1-4), 251-273 (2010)

9. Shahryari-ghoshekandi, R., Sadegh, H.: Kinetic study of the adsorption of synthetic dyes on graphene surfaces. Jordan J. Chem. 9(4), 267-278 (2014)
10. Yagub, M.T., Sen, T.K., Afroze, S., Ang, H.M.: Dye and its removal from aqueous solution by adsorption: a review. Adv. Colloid Interface Sci. 209, 172-184 (2014)

11. Forgacs, E., Cserhati, T., Oros, G.: Removal of synthetic dyes from wastewaters: a review. Environ. Int. 30(7), 953-971 (2004)

12. Mishra, G., Tripathy, M.: A critical review of the treatments for decolourization of textile effluent. Colourage 40, 35 (1993)

13. Purkait, M.K., DasGupta, S., De, S.: Adsorption of eosin dye on activated carbon and its surfactant based desorption. J. Environ. Manag. 76(2), 135-142 (2005)

14. Gupta, V.K.: Application of low-cost adsorbents for dye removal-a review. J. Environ. Manag. 90(8), 2313-2342 (2009)

15. Gupta, V.K., Khamparia, S., Tyagi, I., Jaspal, D., Malviya, A.: Decolorization of Mixture of Dyes: a Critical Review. Global J. Environ. Sci. Manag. 1(1), 71-94 (2015)

16. Iijima, S.: Helical microtubules of graphitic carbon. Nature 354(6348), 56-58 (1991)

17. Das, R., Hamid, S.B.A., Ali, M.E., Ismail, A.F., Annuar, M.S.M., Ramakrishna, S.: Multifunctional carbon nanotubes in water treatment: the present, past and future. Desalin. 354, 160-179 (2014)

18. Iijima, S., Ichihashi, T.: Single-shell carbon nanotubes of 1-nm diameter. Nature 363, 603-605 (1993)

19. Terrones, M.: Science and technology of the twenty-first century: synthesis, properties, and applications of carbon nanotubes. Annu. Rev. Mater. Res. 33(1), 419-501 (2003)

20. Farhat, S., Scott, C.D.: Review of the arc process modeling for fullerene and nanotube production. J. Nanosci. Nanotechnol. 6(5), 1189-1210 (2006)

21. Rafique, M.M.A., Iqbal, J.: Production of carbon nanotubes by different routes-a review. J. Encapsul Adsorp. Sci. 1(02), 29 (2011)

22. Sadegh, H., Shahryari-ghoshekandi, R., Kazemi, M.: Study in synthesis and characterization of carbon nanotubes decorated by magnetic iron oxide nanoparticles. Int. Nano Lett. 4(4), 129-135 (2014)

23. Bahr, J.L., Mickelson, E.T., Bronikowski, M.J., Smalley, R.E., Tour, J.M.: Dissolution of small diameter single-wall carbon nanotubes in organic solvents. Chem. Commun. 2, 193-194 (2001)

24. Chen, R.J., Zhang, Y., Wang, D., Dai, H.: Noncovalent sidewall functionalization of single-walled carbon nanotubes for protein immobilization. J. Am. Chem. Soc. 123, 3838-3839 (2001)

25. Islam, M.F., Rojas, E., Bergey, D.M., Johnson, A.T., Yodh, A.G.: High weight fraction surfactant solubilization of single-wall carbon nanotubes in water. Nano Lett. 3, 269-273 (2003)

26. Richard, C., Balavoine, F., Schultz, P., Ebbesen, T.W., Mioskowski, C.: Supramolecular self-assembly of lipid derivatives on carbon nanotubes. Science 300, 775-778 (2003)

27. O'connell, M.J., Bachilo, S.M., Huffman, C.B., Moore, V.C., Strano, M.S., Haroz, E.H., Rialon, K.L., Boul, P.J., Noon, W.H., Kittrell, C., Ma, J., Hauge, R.H., Weisman, R.B., Smalley, R.E.: Band gap fluorescence from individual single-walled carbon nanotubes. Science 297, 593-596 (2002)

28. Moore, V.C., Strano, M.S., Haroz, E.H., Hauge, R.H., Smalley, R.E., Schmidt, J., Talmon, Y.: Individually suspended singlewalled carbon nanotubes in various surfactants. Nano Lett. 3, 1379-1382 (2003)

29. Bachilo, S.M., Strano, M.S., Kittrell, C., Hauge, R.H., Smalley, R.E., Weisman, R.B.: Structure assigned optical spectra of single walled carbon nanotubes. Science 298, 2361-2366 (2002)

30. Hagen, A., Hertel, T.: Quantitative analysis of optical spectra from individual single-wall carbon nanotubes. Nano Lett. 3, 383-388 (2003)

31. Zorbas, V., Ortiz-Acevedo, A., Dalton, A.B., Yoshida, M.M., Dieckmann, G.R., Draper, R.K., Baughman, R.H., Jose-Yacaman, M., Musselman, I.H.: Preparation and characterization of 
individual peptide wrapped single-walled carbon nanotubes. J. Am. Chem. Soc. 126, 7222-7227 (2004)

32. Zorbas, V., Smith, A.L., Xie, H., Ortiz-Acevedo, A., Dalton, A.B., Dieckmann, G.R., Draper, R.K., Baughman, R.H., Musselman, I.H.: Importance of aromatic content for peptide/singlewalled carbon nanotube interactions. J. Am. Chem. Soc. 127, 12323-12328 (2005)

33. Kam, N.W.S., Dai, H.: Carbon nanotubes as intracellular protein transporters: generality and biological functionality. J. Am. Chem. Soc. 127, 6021-6026 (2005)

34. Zheng, M., Jagota, A., Strano, M.S., Santos, A.P., Barone, P., Chou, S.G., Diner, B.A., Dresselhaus, M.S., Mclean, R.S., Onoa, G.B., Samsonidze, G.G., Semke, E.D., Usrey, M., Walls, D.J.: Structurebased carbon nanotube sorting by sequence-dependent DNA assembly. Science 302, 1545-1548 (2003)

35. Zhang, Y., Bai, Y., Yan, B.: Functionalized carbon nanotubes for potential medicinal applications. Drug Discov. Today. 15(11/12), 428-435 (2010)

36. Jain, N.K., Mishra, V., Mehra, N.K.: Targeted drug delivery to macrophages. Expert Opin. Drug Deliv. 10(3), 353-367 (2013)

37. Jain, A.K., Mehra, N.K., Lodhi, N., Dubey, V., Mishra, D., Jain, N.K.: Carbon nanotubes and their toxicity. Nanotoxicol. 1(3), 167-197 (2007)

38. Kesharwani, P., Ghanghoria, R., Jain, N.K.: Carbon nanotubes exploration in cancer cell lines. Drug Discov. Today. 17(17-18), 1023-1030 (2012)

39. Karousis, N., Tagmatarchis, N., Tasis, D.: Current progress on the chemical modification of carbon nanotubes. Chem. Rev. 110(9), 5366-5397 (2010)

40. Ali, I.: New generation adsorbents for water treatment. Chem. Rev. 112, 5073-5091 (2012)

41. Moradi, O.: Adsorption behavior of basic red 46 by single-walled carbon nanotubes surfaces. Fuller Nanotubes Carbon Nanostruct. 21, 286-301 (2013)

42. Derakhshan, M.S., Moradi, O.: The study of thermodynamics and kinetics methyl orange and malachite green by SWCNTs, SWCNT-COOH and SWCNT-NH 2 as adsorbents from aqueous solution. J. Ind. Eng. Chem. 20(5), 3186-3194 (2013)

43. Sharma, G., Pathania, D., Gupta, V.K., Kothiyal, N.C.: Nanocomposite pectin Zirconium (IV) selenotungstophosphate for adsorptional/photocatalytic remediation of methylene blue and malachite green dyes from aqueous system. J. Ind. Eng. Chem. 21, 957-964 (2015)

44. Bahgat, M., Farghali, A.A., El Rouby, W.M.A., Khedr, M.H.: Synthesis and modification of multiwalled carbon nano-tubes (MWCNTs) for water treatment applications. J. Anal. Appl. Pyrol. 92, 307-313 (2011)

45. Ghaedi, M., Hassanzadeh, A., Kokhdan, S.N.: Multiwalled carbon nanotubes as adsorbents for the kinetic and equilibrium study of the removal of alizarin red S and morin. J. Chem. Eng. Data 56, 2511-2520 (2011)

46. Gupta, V.K., Nayak, A., Bhushan, R., Singh, P.: Biosorption and reuse potential of a blue green alga for the removal of hazardous reactive dyes from aqueous solutions. Biorem. J. 18, 179-191 (2014)

47. Ghaedi, M., Shokrollahi, A., Tavallali, H., Shojaiepoor, F., Keshavarz, B., Hossainian, H., Purkait, M.K.: Activated carbon and multiwalled carbon nanotubes as efficient adsorbents for removal of arsenazo(III) and methyl red from waste water. Toxicol. Environ. Chem. 93, 438-449 (2011)

48. Hu, S.W., Li, W.J., Chang, Z.D., Wang, H.Y., Guo, H.C., Zhang, J.H.: Removal of methyl orange from aqueous solution by magnetic carbon nanotubes. Spectrosc. Spect. Anal. 31, 205-209 (2011)

49. Machado, F.M., Bergmann, C.P., Fernandes, T.H.M., Lima, E.C., Royer, B., Calvete, T.: Adsorption of reactive red M-2BE dye from water solutions by multi-walled carbon nanotubes and activated carbon. J. Hazard. Mater. 192, 1122-1131 (2011)

50. Ghaedi, M., Kokhdan, S.N.: Oxidized multiwalled carbon nanotubes for the removal of methyl red (MR): kinetics and equilibrium study. Desalin. Water Treat. 49, 317-325 (2012)

51. Gupta, V.K., Mohan, D., Saini, V.K.: Adsorption studies on the interaction of some azo dyes (naphthol red-J and direct orange) with nontronite mineral. J. Colloid Interface Sci. 298(1), 79-86 (2006)

52. Mahmoodian, H., Moradi, O., Shariatzadeha, B., Salehf, T.A., Tyagi, I., Maity, A., Asif, M., Gupta, V.K.: Enhanced removal of methyl orange from aqueous solutions by poly HEMA-chitosanMWCNT nano-composite. J. Mol. Liq. 202, 189-198 (2015)

53. Shahryari, Z., Goharrizi, A.S., Azadi, M.: Experimental study of methylene blue adsorption from aqueous solutions onto carbon nano tubes. Int. J. Water Resour. Environ. Eng. 2147483647(2), 016-028 (2010)

54. Rodríguez, A., Ovejero, G., Sotelo, J.L., Mestanza, M., García, J.: Adsorption of dyes on carbon nanomaterials from aqueous solutions. J. Environ. Sci. Health. Part A. 45(12), 1642-1653 (2010)

55. Machado, F.M., Bergmann, C.P., Fernandes, T.H., Lima, E.C., Royer, B., Calvete, T., Fagan, S.B.: Adsorption of Reactive Red M-2BE dye from water solutions by multi-walled carbon nanotubes and activated carbon. J. Hazard. Mater. 192(3), 1122-1131 (2011)

56. Chatterjee, S., Lee, M.W., Woo, S.H.: Adsorption of Congo red by chitosan hydrogel beads impregnated with carbon nanotubes. Bioresour. Technol. 101, 1800-1806 (2010)

57. Chatterjee, S., Chatterjee, T., Lim, S.R., Woo, S.H.: Effect of the addition mode of carbon nanotubes for the production of chitosan hydrogel core-shell beads on adsorption of Congo red from aqueous solution. Bioresour. Technol. 102, 4402-4409 (2011)

58. Bina, B., Amin, M.M., Rashidi, A., Pourzamani, H.: Benzene and toluene removal by carbon nanotubes from aqueous solution. Arch. Environ. Prot. 38, 3-25 (2012)

59. Nadafi, K., Mesdaghinia, A., Nabizadeh, R., Younesian, M., Rad, M.J.: The combination and optimization study on RB29 dye removal from water by peroxy acid and single-wall carbon nanotubes. Desalin. Water Treat. 27, 237-242 (2011)

60. Jahangiri-Rad, M., Nadafi, K., Mesdaghinia, A., Nabizadeh, R., Younesian, M., Rafiee, M.: Sequential study on reactive blue 29 dye removal from aqueous solution by peroxy acid and single wall carbon nanotubes: experiment and theory. Iran. J. Environ. Health. 10(1), 1-8 (2013)

61. Ramazani, S., Ghaedi, M., Mortazavi, K.: Multiwalled carbon nanotubes as efficient adsorbent for the removal of Congo red. Fresenius Environ. Bull. 20, 2514-2520 (2011)

62. Yao, Y.J., He, B., Xu, F.F., Chen, X.F.: Equilibriumand kinetic studies of methyl orange adsorption on multiwalled carbon nanotubes. Chem. Eng. J. 170, 82-89 (2011)

63. Ma, J., Yu, F., Zhou, L., Jin, L., Yang, M.X., Luan, J.S.: Enhanced adsorptive removal of methyl orange and methylene blue from aqueous solution by alkali-activated multiwalled carbon nanotubes. ACS Appl. Mater. Inter. 4, 5749-5760 (2012)

64. Shirmardi, M., Mesdaghinia, A., Mahvi, A.H., Nasseri, S., Nabizadeh, R.: Kinetics and equilibrium studies on adsorption of acid red 18 (azo-dye) using multiwall carbon nanotubes (MWCNTs) from aqueous solution. E. J. Chem. 9, 2371-2383 (2012)

65. Wang, S.B., Ng, C.W., Wang, W.T., Li, Q., Hao, Z.P.: Synergistic and competitive adsorption of organic dyes on multiwalled carbon nanotubes. Chem. Eng. J. 197, 34-40 (2012)

66. Geyikci, F.: Adsorption of acid blue 161 (AB 161) dye from water by multi-walled carbon nanotubes. Fuller Nanotubes Carbon Nanostruct. 21, 579-593 (2013) 
67. Wang, S.B., Ng, C.W., Wang, W.T., Li, Q., Li, L.Q.: A comparative study on the adsorption of acid and reactive dyes on multiwall carbon nanotubes in single and binary dye systems. J. Chem. Eng. Data 57, 1563-1569 (2012)

68. Yu, F., Chen, J.H., Chen, L., Huai, J., Gong, W.Y., Yuan, Z.W.: Magnetic carbon nanotubes synthesis by Fenton's reagent method and their potential application for removal of azo dye from aqueous solution. J. Colloid Interface Sci. 378, 175-183 (2012)

69. Ghaedi, M., Ghobadzadeh, P., Kokhdan, S.N., Soylak, M.: Oxidized multiwalled carbon nanotubes as adsorbents for kinetic and equilibrium study of removal of 5-(4-dimethyl amino benzylidene)rhodanine. Arab J. Sci. Eng. 38, 1691-1699 (2013)

70. Li, Y.H., Du, Q.J., Liu, T.H., Peng, X.J., Wang, J.J., Sun, J.K.: Comparative study of methylene blue dye adsorption onto activated carbon, graphene oxide, and carbon nanotubes. Chem. Eng. Res. Des. 91, 361-368 (2013)

71. Zhou, S.Q., Shao, Y.S., Gao, N.Y., Deng, J., Tan, C.Q.: Equilibrium, kinetic, and thermodynamic studies on the adsorption of triclosan onto multi-walled carbon nanotubes. Clean Soil Air Water 41, 539-547 (2013)

72. Bazrafshan, E., Mostafapour, F.K., Hosseini, A.R., Khorshid, A.R., Mahvi, A.H.: Decolorisation of reactive red 120 dye by using single-walled carbon nanotubes in aqueous solutions. J. Chem. 2013, 938374 (2013)

73. Pan, B., Xing, B.S.: Adsorption Mechanisms of Organic Chemicals on Carbon Nanotubes. Environ. Sci. Technol. 42(24), 9005-9013 (2008)
74. Yang, K., Xing, B.S.: Adsorption of organic compounds by carbon nanomaterials in aqueous phase: Polanyi theory and Its application. Chem. Rev. 110(10), 5989-6008 (2010)

75. Pan, B., Lin, D.H., Mashayekhi, H., Xing, B.S.: Adsorption and hysteresis of bisphenol A and 17 alpha-ethinyl estradiol on carbon nanomaterials. Environ. Sci. Technol. 42(15), 5480-5485 (2008)

76. Ji, L.L., Chen, W., Duan, L., Zhu, D.Q.: Mechanisms for strong adsorption of tetracycline to carbon nanotubes: a comparative study using activated carbon and graphite as adsorbents. Environ. Sci. Technol. 43(7), 2322-2327 (2009)

77. Chen, W., Duan, L., Zhu, D.Q.: Adsorption of polar and nonpolar organic chemicals to carbon nanotubes. Environ. Sci. Technol. 41(24), 8295-8300 (2007)

78. Lin, D.H., Xing, B.S.: Adsorption of phenolic compounds by carbon nanotubes: role of aromaticity and substitution of hydroxyl groups. Environ. Sci. Technol. 42(19), 7254-7259 (2008)

79. Yang, K., Wu, W.H., Jing, Q.F., Zhu, L.Z.: Aqueous adsorption of aniline, phenol, and their substitutes by multi-walled carbon nanotubes. Environ. Sci. Technol. 42(21), 7931-7936 (2008)

80. Mezohegyi, G., Van der Zee, F.P., Font, J., Fortuny, A., Fabregat, A.: Towards advanced aqueous dye removal processes: a short review on the versatile role of activated carbon. J. Environ. Manag. 102, 148-164 (2012) 